
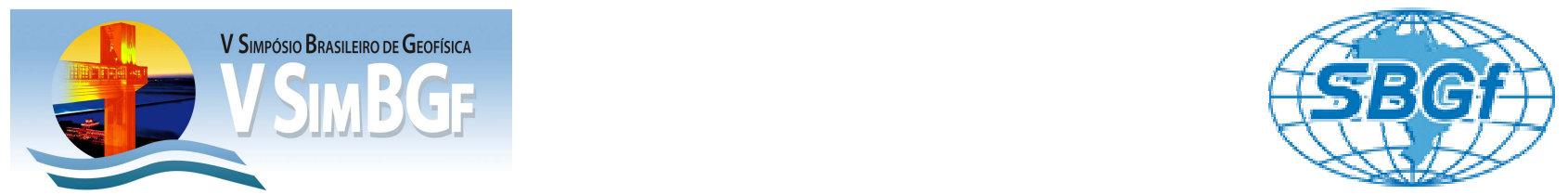

\title{
Geological structures in western edge of Santos basin and adjacent Ribeira belt from broad band magnetotellurics and geological mapping
}

Flora F. Solon, Emanuele F. La Terra, Leonardo G. Miquelutti, Sergio L. Fontes

Observatório Nacional-MCTI,

Copyright 2012, SBGf - Sociedade Brasileira de Geofísica

Este texto foi preparado para a apresentação no V Simpósio Brasileiro de Geofísica, Salvador, 27 a 29 de novembro de 2012. Seu conteúdo foi revisado pelo Comitề Técnico do V SimBGf, mas não necessariamente representa a opinião da SBGf ou de seus associados. É proibida a reprodução total ou parcial deste material para propósitos comerciais sem prévia autorização da SBGt.

\begin{abstract}
During the Neoproterozoic the movement, the collision and the collage of tectonic plates formed a supercontinent called Gondwana. The Ribeira Belt has oriinated from the formation of the supercontinent Gondwana, and extends approximately $1400 \mathrm{~km}$ along the Brazilian coast. It surrounds the Sao Francisco Craton in its southeastern edge, transitioning to the west to the Brasilia Belt. The Ribeira Belt comprises several tectonic lands not yet fully correlated. One can observe Proterozoic volcanicsediments from different source sequences and Neoproterozoic-Eopaleozoic pluton's compositions of both different ages and deformation/metamorphism degrees that have been intruded on the basement. We carried out 81 MT broad band soundings with remote reference, with acquisition frequencies of $4096 \mathrm{~Hz}, 512$ $\mathrm{Hz}$ and $128 \mathrm{~Hz}$. These soundings are distributed into two parallel profiles, approximately $50 \mathrm{~km}$ apart and $5 \mathrm{~km}$ spacing between soundings. . Good quality data were collected in the period range of $0.001-100 \mathrm{~s}$. Data were processed using a robust remote-reference technique. Strike and dimensionality analysis along with G-B decomposition support a general 2-D regional character of the conductivity distribution in the area, allowing us to create a 2-D inversion model. Good misfit can be observed between the measured and calculated transfer functions projected onto the profile direction. These profiles crossed Brasilia and Ribeira Belts, as well as several geosutures in the basement of the marginal basins of southeastern Brazil. The geophysical survey associated with the available geological information brought important contributions to the understanding of the main geosutures presents in the area. Results imaged the two main suture zones between the orogenics belts and allow inferences about the geographic position of their lateral limits.
\end{abstract}

\section{Introduction and Geological Setting}

Eight one MT broad band soundings were acquired, with acquisition frequencies of $4096 \mathrm{~Hz}, 512 \mathrm{~Hz}$ and $128 \mathrm{~Hz}$ for 10 minutes, 30 minutes and 12 hours, respectively. These MT soundings are distributed into two parallel profiles, approximately $50 \mathrm{~km}$ apart, spaced $5 \mathrm{~km}$ with EM field components oriented to the magnetic north and east directions. ADU07 broadband MT systems (Metronix) were used. Typically, three to four MT soundings were measured simultaneously for this study. Both profiles initiate at the coast and continue to the continent direction, as shown in Figure 1.

The geological-geophysical profiles (Figures 1 and 2), of $210 \mathrm{~km}$ each, initiate in the southeast area of the Coastal plain covered by Quaternary sediments along with orthogneiss outcrops of Rio Negro. This is a set of plutonic/gneiss rocks aged about $630 \mathrm{Ma}$, originated in area of magmatic arc pre-collision (Tupinambá et al. 2000). In the relevant break of the Serra do Mar, locally known as Serra da Bocaina, is the Central Tectonic Boundary (CTB). This geosuture (Heilbron et al. 2008) limits the magmatic arc of the Rio Negro Complex (Eastern) with the passive margin of the paleocontinent of Sao Francisco (western).

The sections follow along the western land of the Ribeira Belt. The geological substratum is predominantly formed by banded and biotic gnaisses from the Paraiba do Sul Group and the Embu Complex of yet undefined age of sedimentation, with areas containing metapelitic schist bodies and dolomitic marble. The set is cut by numerous thick granite and granitic gneiss bodies of several generations (Machado Filho et al. 1984; Perrota et al. 2005). In this area lies the Rio Paraiba do Sul Graben, in the system of the southeastern continental rifts (Zalan \& Oliveira 2005), which comprehends the sedimentary basin of Taubaté.

To the west is the limit between Ribeira and Brasilia Belts, occupied by ductile shear zones with different dip angles, such as the one located along the Rio Preto. This corresponds to a geosuture evidenced by gravimetric data (Davino et al 1986). The area occupied by the Brasilia Belt is formed by Archean and Paleoproterozoic basement rocks of part of the Sao Francisco Craton, and tectonically covered by ortho and paragneisses of the Neoproterozoic Socorro Nappe (Campos et al. 1984). 

geological mapping

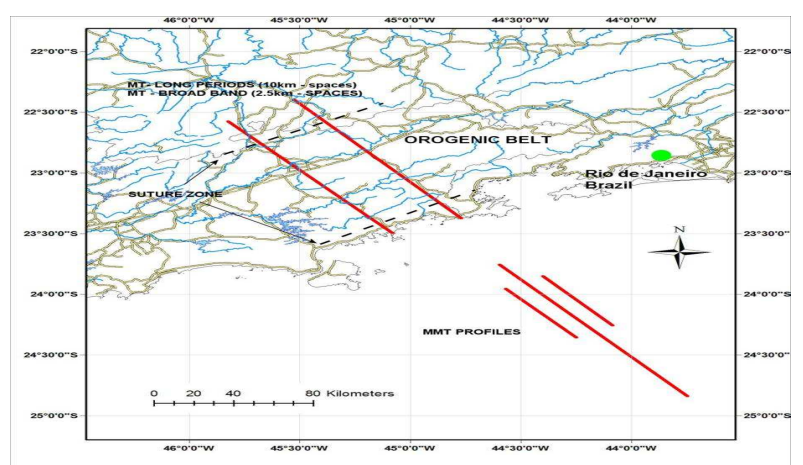

Figure 1 - Onshore and offshore broad band MT profiles.

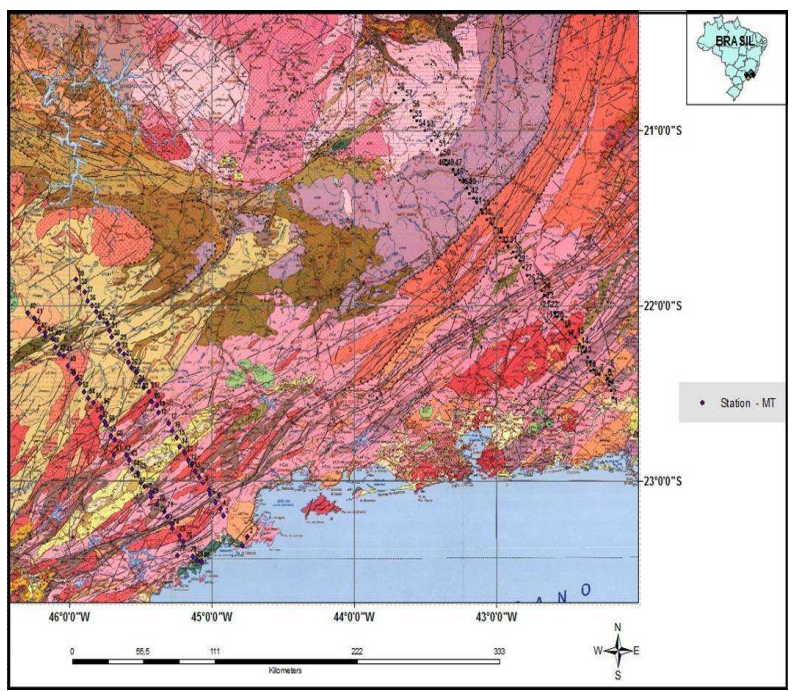

Figure 2 - Geological map with both MT profiles to southwest and to the northeast an MT profile from Figueiredo et al. (2008).

\section{D inversion of the Broad Band MT data}

Data were processed using the robust technique proposed by Egbert \& Booker (1986) with remote reference (Gamble et al, 1979).

Prior to inversion, the data were decomposed following the Groom-Bailey model (GB) (Groom \& Bailey, 1989; Groom et al, 1993, which assumes a 2D regional Earth distorted by 3D superficial heterogeneities

After the unconstrained decomposition of the impedance tensor via $\mathrm{GB}$, we observed a large incidence of results around $10^{\circ}$ for the strike angle. The procedure were repeated constraining the strike angle and allowing the twist and shear to vary freely $\left(-45^{\circ}<\right.$ shear $<459, \quad\left(-60^{\circ}<\right.$ twist $<609$. The expectedly undistorted resulting data were then used for the 2D Inversion.

The 2D inversion were performed using the NLCG algorithm (Winglink (B) software) proposed by Rodi \& Mackie (2001). This routine uses the method of nonlinear conjugate gradients with Tikhonov regularization to the 2$D$ inverse problem for magnetotelluric data. The following parameters were used when running Winglink: a halfspace of $100 \mathrm{ohm} . \mathrm{m}$ was used as starting model and the sea bathymetry and ocean resistivity included. The inversions were unconstrained and we used the smoothed curves. The accepted deviation error was $10 \%$ for TE and TM resistivities and 5\% for TE and TM phase. The regularization parameter tau for smoothing operator used was 3. Final models were obtained after 300 iterations considering the successive adjustments in the initial model. Both TE and TM modes were used simultaneously in the inversion. We assumed the regional geologic strike direction given by the magnetic anomaly map as $65^{\circ}$ (Figure 3 ). The average magnetic declina tion of the region is about $-21^{\circ}$, which means that in the MT set ups, the dipoles were positioned along the east-west direction, thus parallel to the strike direction.

The 2D inversion results are shown in Figures 4 and 5 . The RMS for these inversions is 5.48 for the northern profile and 5.3 for the southern profile.

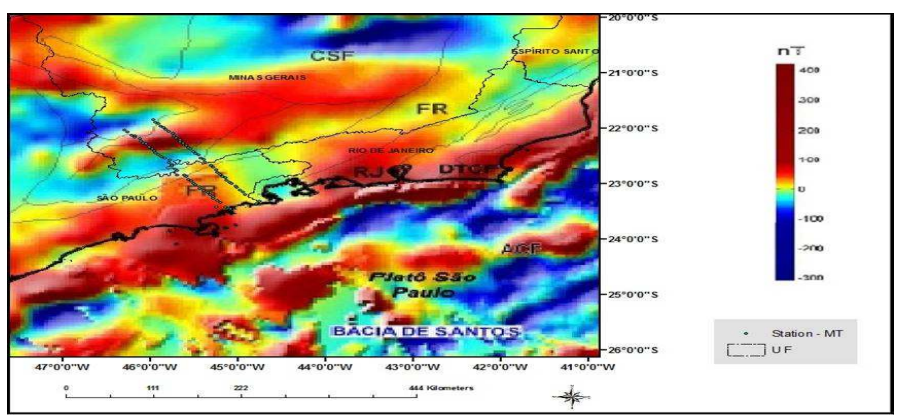

Figure 3 - Total Magnetic Intensity map.

\section{Summary}

The 2D inversion results presented here are preliminary as the MT data were very recently acquired. From the $2 \mathrm{D}$ imaging (Figures 4 and 5), it is possible to infer the presence of an old magmatic arch inserted in the Ribeira Belt in the continental crust that extends up to $40 \mathrm{~km}$. This feature has also been identified before in another MT transect shown in Figueiredo et al. (2008) and displayed in Figure 2. These are characterized for its very high resistive values (> 15,000 ohm.m) and inverted delta shape. Past studies arose some important questions that might be answered, like the basement-cover relationship in the Ribeira-Araçuai orogen (e.g., Campos Neto and Figueiredo, 1995), depth of sutures correspondent to Cambrian collisional orogeny (Schmitt et al., 2004), Neoproterozoic magmatic arc (Campos Neto and Figueiredo, 1995). The Rio Negro Magmatic Arc was formed during one of the stages of the subduction of São Francisco Plate under the plate of the eastern terrain. The Rio Negro magmatic arc corresponds to the Neoproterozoic arc, whose rocks are fundamentally tonalitic gneisses, diorites and gabbros, and intrude the 
metasedimentary sequence. A first interpretation of the structures of continental crust is shown in Figure 4 and 5. It is possible to characterize some geoelectric discontinuities in the lithosphere representing structures of the crust. The mentioned geosuture is probably covered by the Socorro Nappe (strucuture of the superior crust that reaches $9 \mathrm{~km}$ ) that is ductile and deformed in this region. Taubaté basin is very shallow, and is marked by conductive values between soundings 13 and 16 .

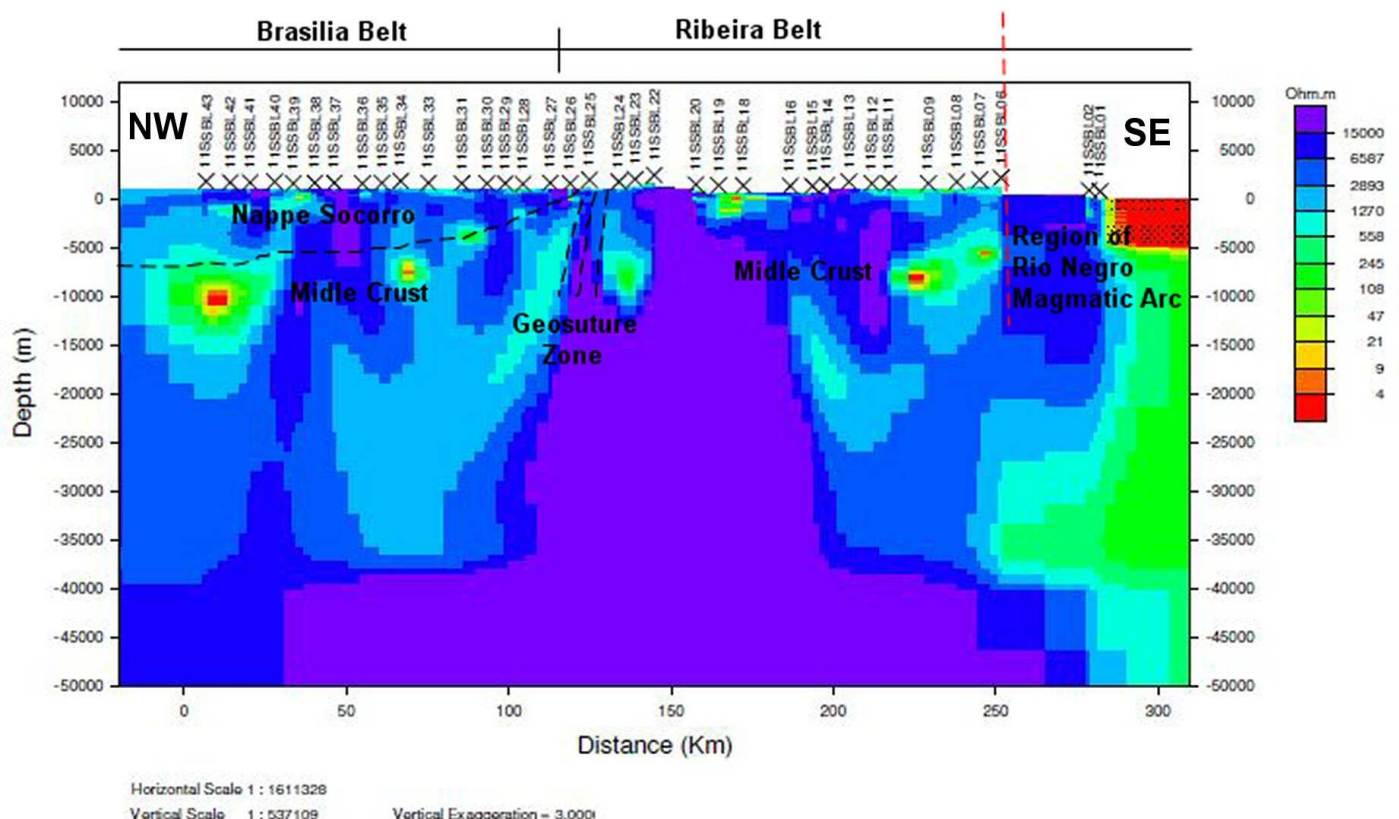

Figure 4-2D inversion of GB decomposed data with geologic interpretation for the northern profile

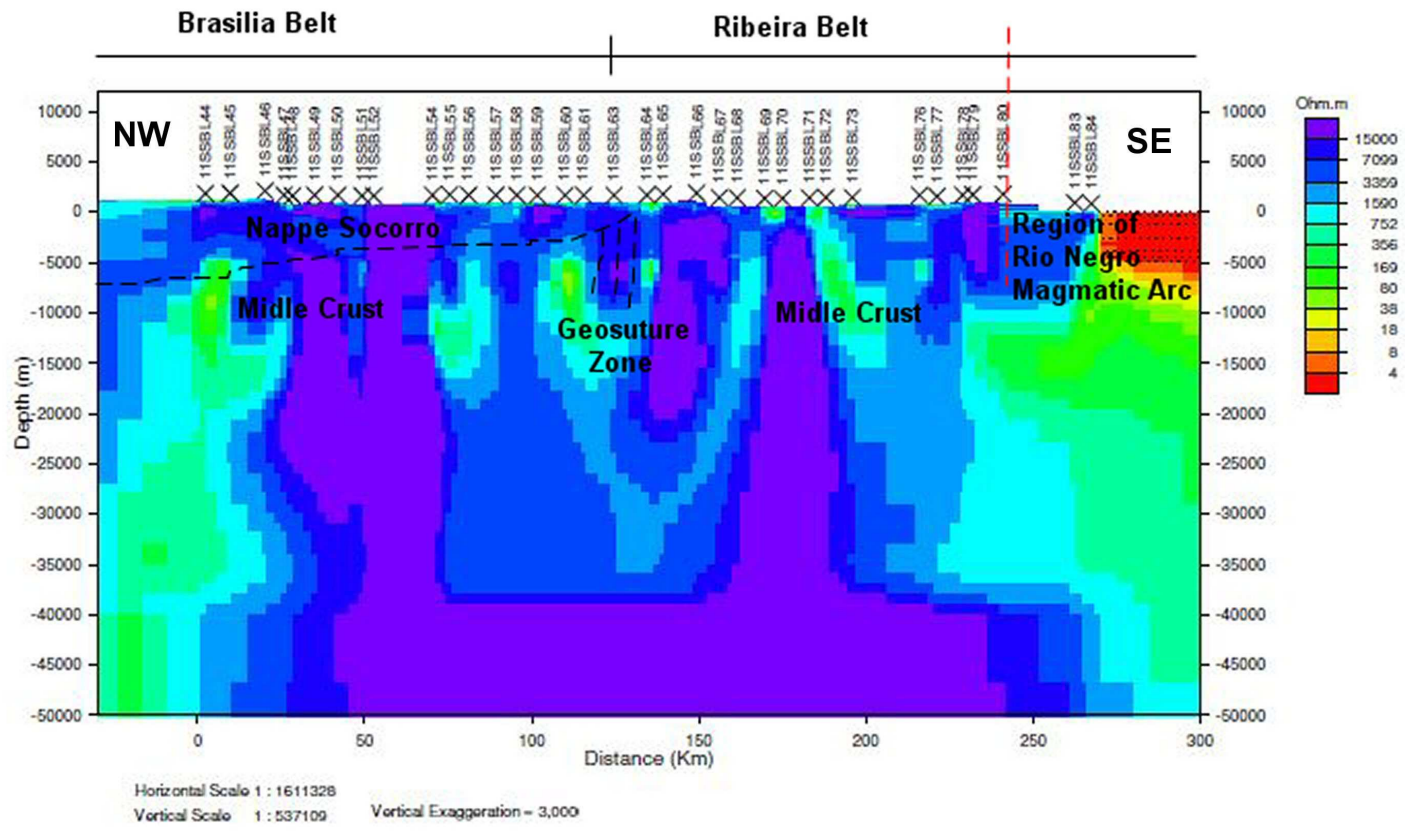

Figure $5-2 D$ inversion of GB decomposed data for the southern profile 


\section{Future Perspectives}

The acquisition of broadband MT data is part of a broader $3 \mathrm{D}$ array project involving gravity, magnetic, long period MT and seismic interferometry data, along with geological surveys.

Further work involves a meticulous full MT dimensionality analysis for both broad band and long period data using the WALDIM code (Marti et al, 2009).

Next steps will involve 3D inversion using the ModEM code (Kelbert \& Egbert, 2012) and 2D joint inversion of multiple geophysical data using the cross-gradient technique as structural constraints (Gallardo \& Meju 2003, 2004, 2007, Gallardo et al., 2012).

\section{Acknowledgments}

We thank Petrobras for funding the project and ANP for sponsoring it. Gary Egbert is acknowledged for providing the EMTF data processing code and Alan Jones for providing the program code used in the strike decomposition. LGM and FFS are grateful to CAPES for the scholarships.

\section{References}

Campos Neto, M.C., Basei, M.A.S., Alves, F.R., Vasconcellos, A.C.B. 1984a. A nappe de cavalgamento Socorro (SPMG). In: CONGR. BRÁS. GEOL., 33. Rio de Janeiro, 1984. Anais. Rio de Janeiro, SBG. v. 4, p. 18091822.

Davino M., Patti I., 1986. Preliminary results of citrus tristeza virus transmission by aphids in Sicily. Proceedings of the Expert's Meeting "Integrated pest control in citrus-groves". Balkema Ed., Rotterdam: 305309.

Egbert, G. D. and Booker, J. R., 1986. Robust Estimation of Geomagnetic Transfer Functions. Geophys. J. Royal Astron. Soc., vol. 87, No 1, p. 173-194.

Egbert, G. D. and Kelbert, A., 2012. Computational recipes for electromagnetic inverse problems. Geophys. J. Int, 189, 1, 251-267.

Meju, M.A., L.A. Gallardo and A.K. Mohamed, Evidence for correlation of 1295 electrical resistivity and seismic velocity in heterogeneous near-surface materials,1296 Geophys. Res. Lett., 30(7), 1373-1376. 2003

Gallardo, L.A. and Meju, M.A., Joint two-dimensional DC resistivity and seismic travel time inversion with crossgradients constraints. Geophys. J. Int., VOL. 109, 2004

Gallardo, L.A. and Meju, M.A., Joint two-dimensional cross-gradient imaging of magnetotelluric and seismic travel-time data for structural and lithological classification. Geophys. J. Int., 169 (3), 1261-1272. 2007

Galllardo, L.A. S.L. Fontes, M.A. Meju, M.P. Buonora, P.P. de Lugao, 2012. Robust geophysical integration through structure-coupled joint inversion and multispectral fusion of seismic reflection, magnetotelluric, magnetic and gravity images: Example from Santos basin, Brazil. Geophysics, in press.

Gamble, T.D., Goubau, W.M. and Clark, J., 1979. Magnetotellurics with a remote magnetic reference. Geophysics, vol 44, 53-68.

Groom, R. W. \& Bailey, R. C., 1989. Decomposition of magnetotelluric impedance tensor in the presence of local three-dimensional galvanic distortion. J. geophys. Res., 94, 1913-1925.

Groom, R. W., Kurtz, R. D., Jones, A. G. and Boerner, D. E., 1993. A quantitative methodology to extract regional magnetotelluric impedances and determine the dimension of the conductivity structure. Geophys. J. Int, 115, 10951118.

Heilbron, M., Valeriano, C.M., Tassinari, C.C.G., Almeida, J.C.H., Tupinamba, M., SIGA, O. \& Trouw, R.A.J. 2008. Correlation of Neoproterozoic terranes between the Ribeira Belt, SE Brazil and its African counterpart: comparative tectonic evolution and open questions. In: Pankhurst, R.J., Trouw, R.A.J., Brito Neves, B.B. \& de Wit, M.J. (eds) West Gondwana: Pre-Cenozoic Correlations Across the South Atlantic Region. Geological Society, London. Special Publications, 294, 211-238.

Kelbert, A \& Egbert, G. D.: Computational recipes for electromagnetic inverse problms. Geophysical Journal International. Vol 189, Issue 1: 251-267, 2012

Machado Filho, L. C. P.; Teixeira, D. L.; Weary, D. M.; Von Keyserlingk, M. A. G.; Hötzel, M. J. 2004. Designing better water troughs: dairy cows prefer and drink more from larger troughs. Applied Animal Behaviour Science, 89: 185-193.

Martí, A., Queralt, P., and Ledo, J., 2009. WALDIM: A code for the dimensionality analysis of magnetotelluric data using the rotational invariants of the magnetotelluric tensor. Computer and Geosciences, 35, 2295-2303.

Perrotta, M.M. et al. Mapa geológico do Estado de São Paulo. São Paulo: CPRM, 2005. Escala 1: 750.000. (Programa Levantamentos Geológicos Básicos do Brasil).

Rodi, W. and Mackie, R., 2001. Nonlinear Conjugate Gradients Algorithm for 2-D Magnetotelluric Inversion. Geophysics, vol. 66, No. 1, p. $174-187$.

Swift, C. M., Jr., 1967. A magnetotelluric investigation of an electrical conductivity anomaly in southwestern United States, PhD thesis, MIT, Cambridge, MA.

Tupinambá M., Teixeira W., Heilbron M. 2000.Neoproterozoic western Gondwana and subduction related plutonism: the role of the Rio Negro Complex in the Ribeira Belt, Southeastern Brazil. Rev. Bras. Geoc., 30:07-11.

Zalan, P.V. \& Oliveira, J. A. B., 2005. Origem e evolução ao estrutural do Sistema de Riftes Cenozoicos do Sudeste do Brasil. Boletim de Geociências da Petrobras, 13(2): 269-300. 